\title{
Development of sustainable procurement monitoring system performance based on Supply Chain Reference Operation (SCOR) and Analytical Hierarchy Process (AHP) on leather tanning industry
}

\author{
Arditya Nur Waaly, ${ }^{1, *}$, Ari Yanuar Ridwan ${ }^{1}$, and Mohammad Deni Akbar ${ }^{1}$ \\ ${ }^{1}$ Industrial Engineering, Faculty of Industrial Engineering, Telkom University, 40257 Bandung, \\ Indonesia
}

\begin{abstract}
Indonesia is increasing from year to year, the increase of the industrial sector is due to the increase of export and domestic demand. Indonesia is also an option for industrial sector because Indonesia is a strategic area besides the cost in Indonesia is quite low. Increased industry will cause environmental damage due to the waste generated and the resources used. environmental damage is increasingly felt, so the government makes the regulation that is Law No.3 of 2014 which contains one of them is the industrial obligation in protecting the environment. the current perceived environmental damage makes people increasingly concerned about the importance of maintaining the environment so as to make changes in product specifications demand. Rules and changes in demand, the industry must implement the aspect of sustainable supply chain management (SSCM). SSCM has an understanding that is integrating financial, environmental, and social in the supply chain. In the implementation of sustainable supply chain required Key Performance Indicator which aims to monitor and measure the performance of companies in the application of sustainable. KPI obtained from the implementation of the SCOR model is by mapping the business process of the company in SCOR model, so that obtained 14 KPI in accordance with the company's business processes and support the sustainable implementation. KPI obtained is verified on the company to obtain KPI that can be applied at this time and got 8 KPI selected which then done weighting using AHP, weight is used to calculate the sustainable performance of company. In performing monitoring and performance measurement tools are needed in monitoring. currently the company has not monitoring system so that company can not monitor and measure performance well which resulted barrier of company in applying of sustainable supply chain.
\end{abstract}

* Corresponding author: arditya.nurwaaly@gmail.com 


\section{Introduction}

Industrial developments in Indonesia are increasing. The development of industrial sector can be seen one of the amount and income of export. The development of the industrial sector has a negative impact according to (Ita, 2007) namely the occurrence of environmental pollution, the emergence of the nature konsumenisme, industrial waste that damage the environment. One of the emerging industries today is the leather industry. Can be seen in Figure 1 is the development of skin exports from year to year.

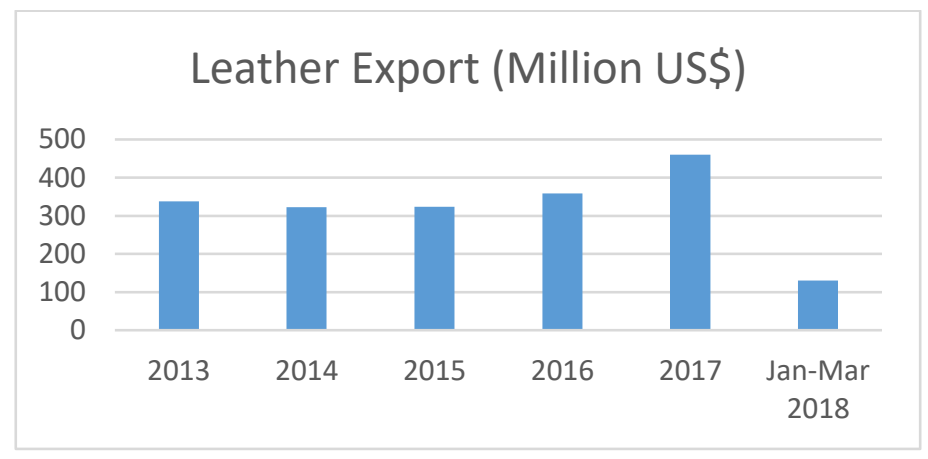

Fig 1. Indonesian Leather Export Million US \$

Source: (Ministry of Industry of the Republic of Indonesia, 2018)

It can be seen from Figure 1, the amount of revenue from the export of leather products Indonesia is large enough. The increasing demand on the skin will increase the number of industries moving on the tannery. Figure 2 shows the number of tannery industries per year from 2010 to 2013.

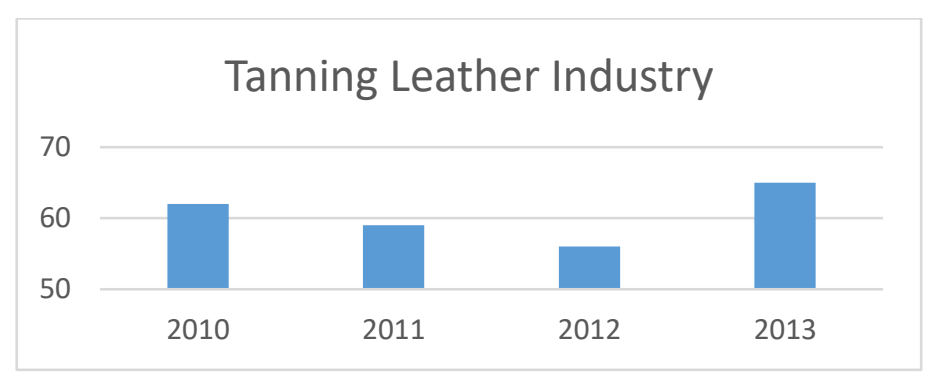

Fig 2. Tanning Leather Industry

Source: (Ministry of Industry of the Republic of Indonesia, 2018)

Indonesia has several centers of leather industry namely Garut, Mageranm, Madiun, and Yogyakarta. This research was conducted on one of leather tannery industry in Garut. In this company the process of tannery using chemicals. The tannery uses chemicals applied because it is cheaper, faster, and good results. There are 130 chemicals from all recipes and processes performed. Currently the waste generated has not been done waste processing that makes the waste become safe and reusable, so the waste discharged into the river, causing environmental damage one of them Cimanuk River indicated contaminated.

Environmental damage is increasingly perceived by the government to make regulations regulating the industry concerning the environment, namely Law No.3 Year 2014 article 30 which contains industrial obligations to make natural resource utilization planning starting from product design, production process, optimization of product waste, and waste treatment. 
In addition to existing regulations, the community is now aware of the importance of maintaining the environment because of the perceived impact is increasingly felt that causes changes in demand for products that require the product to apply environmental aspects ranging from product manufacturing process to the end of product life.

In accordance with the regulations and requests it is necessary to implement sustainable supply chain management (SSCM), SSCM according to (Craig R. Carter, 2008) is the integration between the financial, environmental and social aspects of the supply chain.

KPI is useful for measuring monitoring daan from company performance, in this research focuses on procurement. Procurement is important because procurement is an important activity (Ridwan, 2015) because effective product procurement will lead to better environmental control and better prices for resale. In the procurement section (Rdiwan, 2016), significant cost savings related to the reduction of the number of suppliers and negotiation agreement. Currently the company does not have a system that helps in analyzing, and monitoring on the issue of sustainable application to the company. To assist companies in monitoring and analyzing of performance in implementing sustainable need to be assisted by good information system, to help it need to make monitoring system.

In the monitoring system required KPI which is the content of the monitoring system to assist companies in the implementation of sustainable procurement, so it is necessary to make KPI which aims to evaluate the performance. KPI obtained using Supply Chain Operation Reference (SCOR) and after obtained verification by the company so obtained KPI elected, currently the company does not have a sustainable KPI and the company does not have a monitoring system that supports sustainable supply chain system so that performance indicators can not be measured and monitored well, this has resulted in the company's difficulty in achieving sustainable supply chain as the demands of government and society.

\section{Study of Literature}

\subsection{Supply Chain Management (SCM)}

Understanding Supply Chain Management (SCM) is SCM is the integration of business processes from end users through initial suppliers that provide products, services, and information that add value to customers (Douglas, Martha, \& Janus, 1998).

\subsection{Sustainable Supply Chain Management (SSCM)}

Susitainability Supply Chain Management (SSCM) (Craig R. Carter, 2008) is the integration and achievement of the organization in integrating social, environmental, and economic aspects of the company's business processes to improve the economic performance of the company and supply chain. The environmental aspect of Suistanibility aims to minimize or eliminate waste including hazardous chemicals, emissions, energy and solid waste along the supply chain. Where the supply chain starts from product design, material selection, manufacturing process, final product delivery to customer and end of life product management.

\subsection{Supply Chain Operation Reference (SCOR)}

One way of measuring supply chain performance is by using the Supply Chain Operation Reference (SCOR) method. This method was introduced by the Supply Chain Council (SCC) as a model of supply chain performance measurement across industries (Wigaringtyas, 2013). The SCOR model is useful for descripting and analyzing the supply chain. The SCOR model uses three individual techniques: business process modeling, performance benchmarking and field analysis and turning into an integrated approach (Georgise, 2013). 
In SCOR there are 4 levels. Level 1 is Top Level aims to define the content of SCOR model which contains plan, source, make, deliver, and return. Level 2 aims to detail the processes performed in the core process, there are 3 types of production: make to stock, make to order, and engineering to order. Level 3 is the decomposition stage of each process that defines the ability of the company, there are 5 attributes of reliability, responsiveness, agility, cost, and assets. Level 4 is the implementation stage so that the happening perbuhana kondisis business.

\subsection{Analytical Hierarchy Process (AHP)}

Analytical Hierarchy Process (AHP) is a decision support model developed by Thomas L. Saaty. AHP describes complex multi-factor or multi-criteria issues into a hierarchy. In this ahp determined which alternatives are best with attention to the criteria that affect the best alternative retrieval.

The steps in Analytical Hierarcy Process (Setyaningsih Ira. 2011) are:

1. Create criteria in matrix

2. Normalization of matriks

3. Sum of field $i$

4. Determine the priority vector

5. Calculate the eigen value

6. Calculate consistency index (CI)

7. Below is a comparison scoring scale between the alternatives

Table 1. Comparison Scoring

\begin{tabular}{|c|c|}
\hline Intensity of Interest & Information \\
\hline 1 & Both elements are equally important \\
\hline 3 & One element is slightly more important than the other elements \\
\hline 5 & One element is more important than other elements \\
\hline 7 & One element is clearly more absolutely essential than other elements \\
\hline 9 & One element is absolutely essential from other elements \\
\hline $2,4,6,8$ & The values between two adjacent value judgments \\
\hline $2,4,6,8$ & $\begin{array}{l}\text { Contrary If for the activity } \mathrm{i} \text { gets one number compared with activity } \mathrm{j} \text {, } \\
\text { then } \mathrm{j} \text { has the opposite value with } \mathrm{i}\end{array}$ \\
\hline
\end{tabular}




\subsection{Normalisasi Snorm De Boer}

Performance measurement can be done in several ways, performance fulfillment is defined by normalisai of performance indicators. The normalization process is called normalization of Snorm De Boer, ie (Sumiati, 2012)

Where :

$$
\text { Snorm }(\mathrm{SKOR})=\frac{\mathrm{si}-\mathrm{Smin}}{(\mathrm{Smax}-\mathrm{Smin})} \times 100
$$

$\mathrm{Si}=$ Actual Value

Smin $=$ Bad achievement value

Smax $=$ good achievement value

From the normalization result is converted in the range 0 to 100 , so it can see the status of the performance. Below is a permanent indicator

Table 2. Normalisasi Snorm De Boer

\begin{tabular}{|c|c|}
\hline Sistem Monitoring & Performance Indicator \\
\hline$<40$ & Poor \\
\hline $40-50$ & Marginal \\
\hline $50-70$ & Average \\
\hline $70-90$ & Good \\
\hline$>90$ & Excellent \\
\hline
\end{tabular}

\subsection{Monitoring System}

Monitoring system has several advantages that know the comprehensive description of the system, formulate policies in various conditions to support the system, knowing the dynamic model of supply chain management in the system.(Ridwan, 2015)

\section{Research Methodology}

In this research there are several steps need obtained, which are:

1. Input from this research are stakeholder, business process procurement, and sustainable objective

2. The input results are mapped on the SCOR model

3. The result of SCOR model is obtained KPI sustainable procurement

4. After obtaining a sustainable KPI conducted veriikasi by the company so obtained KPI selected

5. fter KPI verification is done weighing using AHP method on attribute and KPI

6. Weighted on KPI performed performance calculations using Snorm De Boer normalization of each KPI

7. Verifiable KPIs are made to design a monitoring system

8. Output in this research is application of sustainable procurement monitoring system 


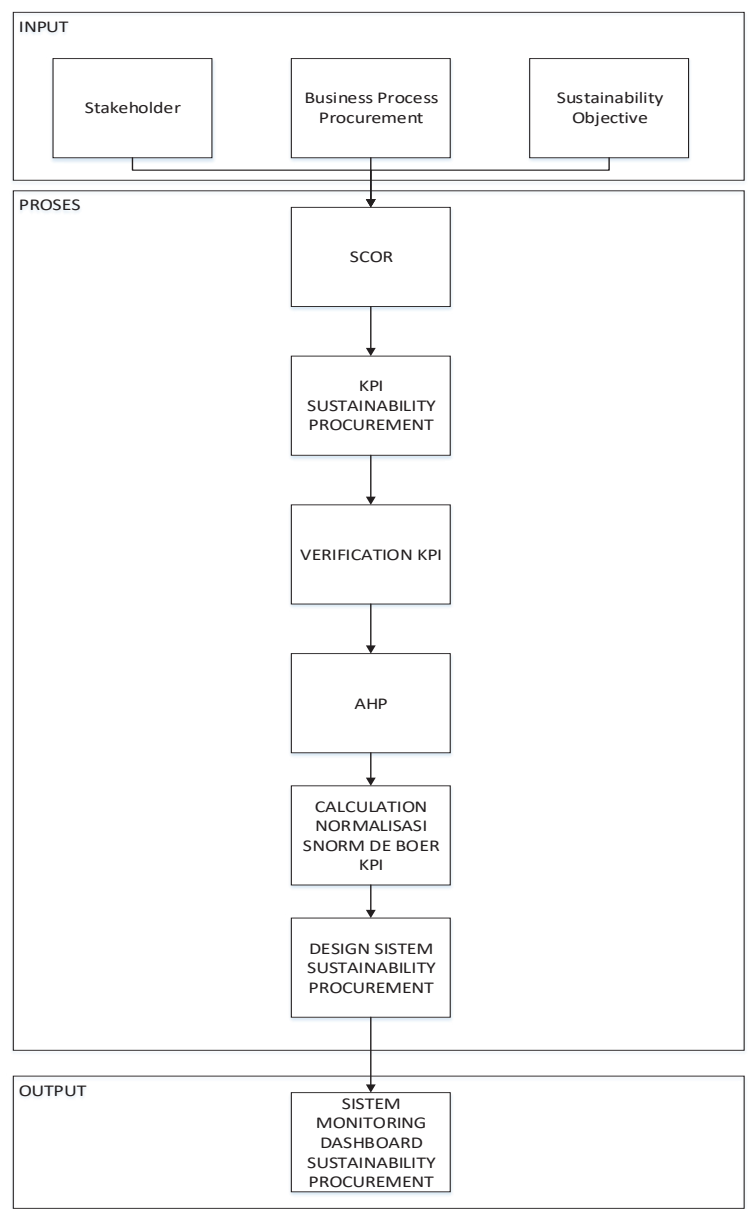

Fig 3. Methodology 


\section{Result and Analysis}

\subsection{Identification of Sustanable Objective}

At this stage the determination of the objectives achieved by the company in the procurement process for the implementation of sustainable supply chain, the determination of objectives conducted by the company stakeholders and based on the needs of the company. The following sustainable objectives can be seen in Table 3 .

Table 3. Sustainable Objective

\begin{tabular}{|c|l|l|}
\hline No & \multicolumn{1}{|c|}{ sustainability Objective } & \multicolumn{1}{c|}{ Stakeholder } \\
\hline 1 & Selection of the right supplier & $\begin{array}{l}\text { Supplier, purchasing division, } \\
\text { inventory division, accounting / } \\
\text { finance / administration }\end{array}$ \\
\hline 2 & Use of environmentally friendly materials & Supplier, purchasing division \\
\hline 3 & Minimize dangerous materials & Supplier, purchasing division \\
\hline 4 & Lowest cost & $\begin{array}{l}\text { Supplier, purchasing division, } \\
\text { financial division }\end{array}$ \\
\hline
\end{tabular}

\subsection{Business Process with SCOR Method Approach}

Below is an explanation of each process on business processes procurement at SCOR by considering aspects of Sustainability. In Table 4 we can see the procurement business process with SCOR method approach.

Table 4. Business Process Procurement with SCOR Method Approach

\begin{tabular}{|c|c|c|}
\hline \multicolumn{3}{|c|}{ Planning } \\
\hline Level 1 & Level 2 SCOR & Activity \\
\hline Source Planning & $\begin{array}{l}\text { sP2.4 Manage Supplier } \\
\text { Agreements }\end{array}$ & $\begin{array}{l}\text { Determining sustainable Requirements dan } \\
\text { sustainable objective }\end{array}$ \\
\hline \multicolumn{3}{|c|}{ Exercutions } \\
\hline Level 1 & Level 2 SCOR & Activity \\
\hline \multirow[t]{7}{*}{$\begin{array}{l}\text { Source Make To } \\
\text { Order }\end{array}$} & $\begin{array}{l}\text { sS2.1 Identify Sources } \\
\text { of Supply }\end{array}$ & $\begin{array}{l}\text { Finding for suppliers of leather and } \\
\text { chemicals }\end{array}$ \\
\hline & $\begin{array}{l}\text { sS2.2 Select Final } \\
\text { Supplier and Negotiate }\end{array}$ & $\begin{array}{l}\text { Selecting suppliers that already have } \\
\text { environmental standardization and material } \\
\text { cost }\end{array}$ \\
\hline & $\begin{array}{l}\text { sS2.3 Schedule Product } \\
\text { Deliveries }\end{array}$ & Schedule delivery of raw materials \\
\hline & sS2.4 Receive Product & Receiving material ordered \\
\hline & sS2.5 Verivy Product & $\begin{array}{l}\text { Check the material received in accordance } \\
\text { with the purchase order }\end{array}$ \\
\hline & sS2.6 Transfer Product & $\begin{array}{l}\text { Submit the material to production or } \\
\text { warehouse }\end{array}$ \\
\hline & $\begin{array}{l}\text { sS2.7 Authorize } \\
\text { Supplier Payment }\end{array}$ & $\begin{array}{l}\text { Make payment to supplier according to } \\
\text { verified invoice }\end{array}$ \\
\hline \multicolumn{3}{|c|}{ Enable } \\
\hline Level 1 & Level 2 SCOR & Activity \\
\hline
\end{tabular}




\begin{tabular}{|l|l|l|}
\hline Enable Source & $\begin{array}{l}\text { sES.2 Assess Supplier } \\
\text { Performance }\end{array}$ & Assess supplier performance \\
\hline & & Create a procurement report \\
\hline & $\begin{array}{l}\text { sES.8 Manage } \\
\text { Import/Export } \\
\text { Requirements }\end{array}$ & Manage import export requirements \\
\hline
\end{tabular}

\subsection{Structure of KPI Sustainable}

The designed KPI (Performance Index Index) includes measurement of company performance from all Procurement processes. The structure of KPI is the preparation of KPI in accordance with the Green Objective category. KPI is divided from 5 attributes that is reliabilit, responsiveness, agility, cost, asset KPIs can be seen in Table 5

Table 5. Structure of KPI

\begin{tabular}{|c|c|c|}
\hline & & TRIK \\
\hline Level 1 & Level 2 & (Level 3) \\
\hline \multirow{14}{*}{$\begin{array}{l}\text { Source Engineer To } \\
\text { Order }\end{array}$} & \multirow{6}{*}{$\begin{array}{l}\text { sS3.1 Identify source } \\
\text { of supply }\end{array}$} & Purchased Material Cost \\
\hline & & Source cycle time \\
\hline & & Identify source of supply cycle time \\
\hline & & $\%$ material that is biodegradable \\
\hline & & $\%$ hazardous material in inventory \\
\hline & & \% Material Recycled / Reused \\
\hline & \multirow{3}{*}{$\begin{array}{l}\text { sS3.2 Select Final } \\
\text { Supplier and } \\
\text { Negotiates }\end{array}$} & \% supplier with an EMS or ISO 14001 \\
\hline & & $\begin{array}{l}\% \text { Of employee trained on environmental } \\
\text { requirements }\end{array}$ \\
\hline & & $\begin{array}{l}\% \text { Of supplier meeting environmental metric } \\
\text { criteria }\end{array}$ \\
\hline & $\begin{array}{l}\text { sS3.3 Schedule } \\
\text { product Deliveries }\end{array}$ & $\begin{array}{l}\text { \% Schedules Changed within Supplier's Lead } \\
\text { Time }\end{array}$ \\
\hline & sS3.4 Receive Product & $\begin{array}{c}\% \text { Orders/ Lines Received On-Time To Demand } \\
\text { Requirement }\end{array}$ \\
\hline & \multirow{3}{*}{ sS3.5 Verify Product } & $\begin{array}{c}\% \text { Pesanan yang diterima dengan kadar yang } \\
\text { tepat }\end{array}$ \\
\hline & & $\%$ Orders/ Lines Received Defect Free \\
\hline & & $\%$ Orders $/$ lines received damage free \\
\hline
\end{tabular}




\begin{tabular}{|c|c|c|}
\hline & $\begin{array}{c}\text { sS3.6 Transfer } \\
\text { Product }\end{array}$ & $\begin{array}{c}\text { \% Product Transferred On-Time to Demand } \\
\text { Requirement }\end{array}$ \\
\cline { 2 - 3 } & $\begin{array}{c}\text { sS3.7 Authorize } \\
\text { Supplier Payment }\end{array}$ & Authorize Supplier Payment Cycle Time \\
\hline
\end{tabular}

\subsection{Identification sustainable KPI}

Sustainable KPI is determined to measure how much the company achieves in the application of sustainable procurement. The sustainable KPI identification is performed using supply chain operation reference (SCOR) based on the specified sustainbale objective. can be seen in Table 6

Table 6. Definition and attribute KPI

\begin{tabular}{|c|c|c|}
\hline KPI & Definisi & Attribute \\
\hline $\begin{array}{l}\text { \% supplier with an EMS or ISO } \\
14001\end{array}$ & $\begin{array}{l}\text { Percentage of already certified } \\
\text { environmental suppliers }\end{array}$ & Reliability \\
\hline $\begin{array}{l}\text { Select supplier and negotiate } \\
\text { cycle time }\end{array}$ & $\begin{array}{l}\text { The time required to select suppliers and } \\
\text { negotiations }\end{array}$ & Responsiveness \\
\hline source cycle time & Time needed to identify resources & Responsiveness \\
\hline $\begin{array}{l}\text { Authorize Supplier Payment } \\
\text { Cycle Time }\end{array}$ & The time it takes to pay the supplier & Responsiveness \\
\hline $\begin{array}{l}\% \text { of material that are } \\
\text { recycleable / reuseable }\end{array}$ & $\begin{array}{l}\text { Percentage of materials that can be } \\
\text { recycled or reused for the production } \\
\text { process of the total material available }\end{array}$ & Asset \\
\hline$\%$ material that is biodegradable & $\begin{array}{l}\text { Percentage of material that } \\
\text { microorganisms can break down from the } \\
\text { total material }\end{array}$ & Asset \\
\hline $\begin{array}{l}\text { \% Schedules Changed within } \\
\text { Supplier's Lead Time }\end{array}$ & $\begin{array}{l}\text { The percentage of suppliers changes lead } \\
\text { times }\end{array}$ & Reliability \\
\hline $\begin{array}{l}\text { \% Orders/ Lines Received On- } \\
\text { Time To Demand Requiremen }\end{array}$ & Percentage of order arrival on time & Responsiveness \\
\hline $\begin{array}{l}\% \text { Orders/ Lines Received } \\
\text { Defect Free }\end{array}$ & $\begin{array}{l}\text { Percentage of orders that come there is no } \\
\text { defect }\end{array}$ & Reliability \\
\hline$\%$ orders with correct content & $\begin{array}{l}\text { The percentage of orders received with } \\
\text { the right amount }\end{array}$ & Reliability \\
\hline $\begin{array}{l}\% \text { of supplier meeting } \\
\text { environmental metric criteria }\end{array}$ & $\begin{array}{l}\text { Percentage of suppliers who meet agreed } \\
\text { environmental criteria divided by total } \\
\text { suppliers listed in the company }\end{array}$ & Reliability \\
\hline
\end{tabular}




\begin{tabular}{|l|l|l|}
\hline $\begin{array}{l}\text { \% hazardous material in } \\
\text { inventory }\end{array}$ & $\begin{array}{l}\text { Percentage of hazardous material to the } \\
\text { supply of total material weight on } \\
\text { inventory }\end{array}$ & Asset \\
\hline $\begin{array}{l}\text { \% Orders/lines received } \\
\text { damage free }\end{array}$ & $\begin{array}{l}\text { Percentage of incoming orders there is no } \\
\text { damage }\end{array}$ & Reliability \\
\hline Purchased material cost & Total cost when procuring & Cost \\
\hline
\end{tabular}

\subsection{Verification KPI}

KPI verification is performed to determine the appropriate KPI and will be used in the measurement. KPI verification is done by stakeholders in the company. The results of KPI verification can be seen in Table 7 below

Table 7. KPI Verification

\begin{tabular}{|l|l|}
\hline No & \multicolumn{1}{|c|}{ KPI } \\
\hline 1 & $\%$ supplier with an EMS or ISO 14001 \\
\hline 2 & source of supply cycle time \\
\hline 3 & $\%$ of supplier meeting environmental metric criteria \\
\hline 4 & $\%$ order with correct content \\
\hline 5 & $\%$ of materials that are recycleable/reuseable \\
\hline 6 & $\%$ hazardous material \\
\hline 7 & $\%$ material that is biodegradable \\
\hline 8 & Purchased material cost \\
\hline
\end{tabular}

\subsection{KPI weighting}

In this process, KPI weighting has been verified, weighted using AHP method. There are 3 pairwise matrix matrix which is paired pair comparison matrix, paired comparison matrix KPI attribute reliability, and paired comparison matrix KPI attribute asset. The result of weighting each attribute and KPI multiplied so as to get the final weight. The results of weighting calculations can be seen in Table 8 :

Table 8. KPI Weighting

\begin{tabular}{|c|l|l|l|l|}
\hline \multicolumn{1}{|c|}{ Attribute } & Bobot & KPI & Bobot & Bobot Akhir \\
\hline Realibility & 0,277 & $\begin{array}{l}\text { \% order with correct } \\
\text { content }\end{array}$ & 0,312 & 0,086458 \\
\hline & $\begin{array}{l}\text { \% of supplier meeting } \\
\text { environmental metric } \\
\text { criteria }\end{array}$ & 0,222 & 0,061456 \\
\hline
\end{tabular}




\begin{tabular}{|l|l|l|l|l|}
\hline & & $\begin{array}{l}\text { \% supplier with an EMS or } \\
\text { ISO 14001 }\end{array}$ & 0,465 & 0,128788 \\
\hline Responsiveness & 0,257 & Source Cycle Time & 1 & 0,257 \\
\hline Cost & 0,244 & Purchased material cost & 1 & 0,244 \\
\hline Asset & 0,223 & $\begin{array}{l}\text { \% of materials that are } \\
\text { recycleable/reuseable }\end{array}$ & 0,3269 & 0,072872 \\
\hline & & $\begin{array}{l}\text { \% hazardous material } \\
\text { \% material that is } \\
\text { biodegradable }\end{array}$ & 0,3462 & 0,077178 \\
\hline & & 0,3269 & 0,078288 \\
\hline
\end{tabular}

\subsection{Normalisasi Snorm De Boer}

Below is an example of the normalization calculation of Snorm De Boer. Snorm de boer calculation to find the value of company's achievement in applying sustainable, in each KPI has value and all value of KPI is notified to be the value of process performance source from company. Normalization Snorm De boer can be seen in Table 9:

Table 9. Normalisasi Snorm De Boer

\begin{tabular}{|c|c|c|c|c|c|c|c|}
\hline KPI & Actual & Min & Max & $\begin{array}{c}\mathrm{SNO} \\
\mathrm{RM}\end{array}$ & $\begin{array}{c}\text { Weighti } \\
\text { ng }\end{array}$ & $\begin{array}{c}\text { SNOR } \\
\text { M x } \\
\text { Weigh } \\
\text { ting }\end{array}$ & $\begin{array}{c}\text { Tota } \\
1 \\
\text { Poin } \\
t\end{array}$ \\
\hline $\begin{array}{l}\% \text { order with } \\
\text { correct content }\end{array}$ & 53,2 & 40 & 100 & 22 & 0,086 & 1,9 & \\
\hline $\begin{array}{l}\text { \% of supplier } \\
\text { meeting } \\
\text { environmental } \\
\text { metric criteria }\end{array}$ & 62,5 & 55 & 100 & 16,67 & 0,061 & 1,02 & \\
\hline $\begin{array}{l}\text { \% supplier with } \\
\text { an EMS or ISO } \\
14001\end{array}$ & 65,2 & 52 & 100 & 27,5 & 0,129 & 3,54 & 6,47 \\
\hline $\begin{array}{l}\text { \%Source Cycle } \\
\text { Time }\end{array}$ & 95,7 & 70 & 100 & 85,67 & 0,257 & 21,98 & $\begin{array}{l}21,9 \\
8\end{array}$ \\
\hline $\begin{array}{l}\text { Purchased } \\
\text { material cost }\end{array}$ & $\begin{array}{l}22065000 \\
00\end{array}$ & $\begin{array}{l}23040050 \\
00\end{array}$ & $\begin{array}{l}212040500 \\
0\end{array}$ & 53,11 & 0,244 & 12,94 & $\begin{array}{l}12,9 \\
4\end{array}$ \\
\hline $\begin{array}{l}\% \text { of materials } \\
\text { that are } \\
\text { recycleable/reuse } \\
\text { able }\end{array}$ & 45,5 & 40 & 100 & 9 & 0,073 & 0,66 & \\
\hline $\begin{array}{l}\% \text { hazardous } \\
\text { material }\end{array}$ & 58,8 & 70 & 0 & 16 & 0,077 & 1,23 & \\
\hline $\begin{array}{l}\% \text { material that is } \\
\text { biodegradable }\end{array}$ & 53,2 & 45 & 100 & 14,91 & 0,073 & 1,09 & 2,98 \\
\hline \multicolumn{7}{|c|}{ TOTAL } & $\begin{array}{l}44,3 \\
7 \\
\end{array}$ \\
\hline
\end{tabular}

From the above results can be seen examples of calculations to get the performance measurement value of each KPI. The total of all KPIs is 44.37 included in the Marginal category, so it is necessary to improve the performance of each KPI. 


\subsection{Aplication System Monitoring}

\subsubsection{Homepage}

Homepage dashboard is the initial interface page when user opens the dashboard. On the homepage dashboard there are performance measurement results of the entire process of the company. Homepage in addition to displaying the performance of the entire process of the company also displays the performance of each process on level 1 of the process of source, make, deliver, and display the attributes of each process. Homepage dashboard can be seen in Figure 4.

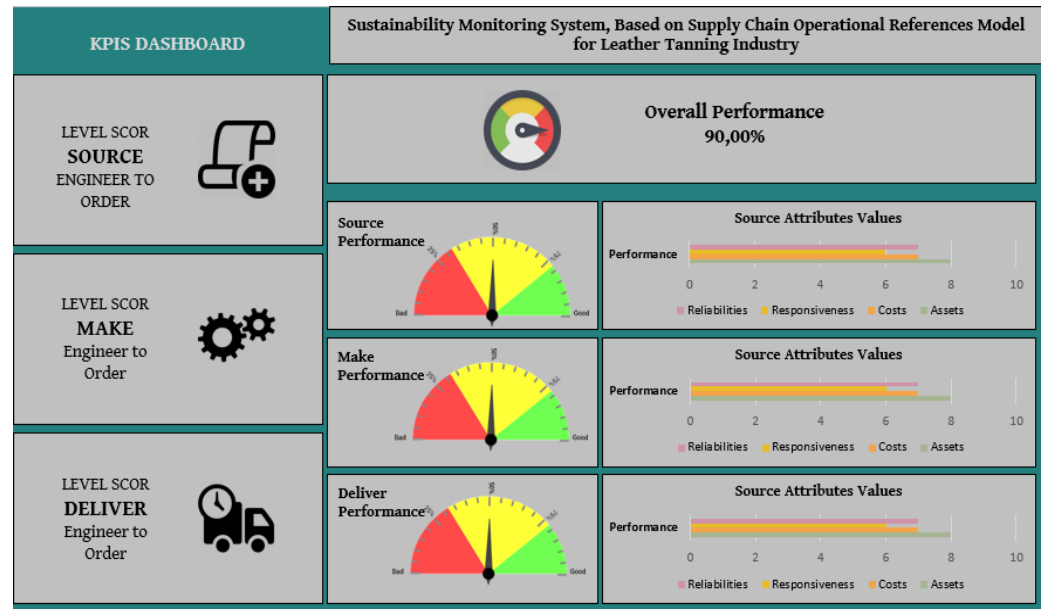

Fig 4. Homepage Dashboard

\subsubsection{Level 2 Dashboard}

On dashboard level 2 menjelaskan proses-proses yang terdapat pada source engineer to order, terdapat 7 pilihan proses yang dimana pada setiap proses memiliki KPI. Level 2 dashboard can be seen in Figure 5. 


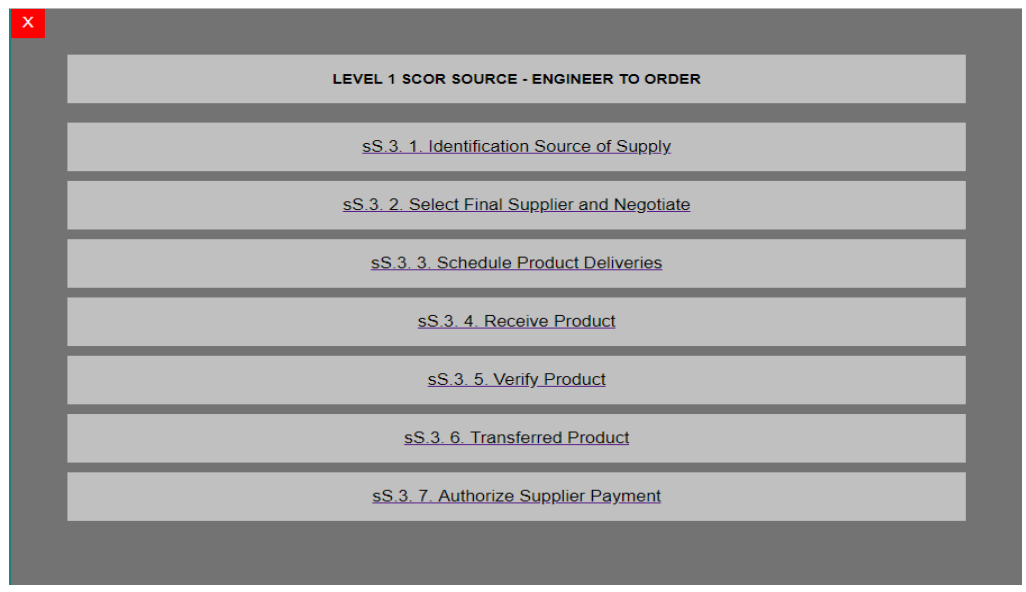

Fig 5. Level 2 Dashboard

\subsubsection{KPI dashboard}

All sustainable KPIs are created dashboards in which each KPI has 3 graphs, in the first graph explains the KPI's history data for 16 quarters, the second graph describes the average of 16 quarters, and the third graph contains the current data or the last quarter. The example of KPI dashboard below is KPI Supplier with an EMS or Cerification ISO 14001. KPI dashboard can be seen in Figure 6.
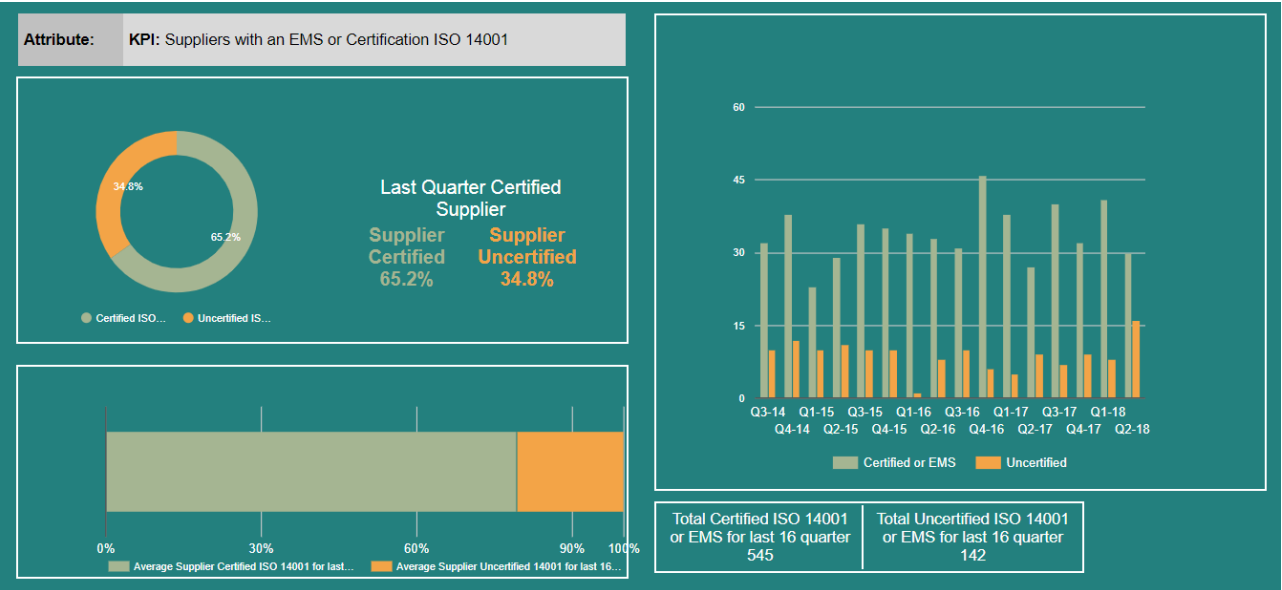

Fig 6. Homepage Dashboard

There are 3 graphs on KPI Supplier with an EMS or Cerification ISO 14001, Here is an explanation of the graph:

1. Last quarter certified supplier: on the graph there is a percentage of performance of the KPI, the last quarter supplier certified amounted to $65.2 \%$, The value is obtained from the 
total supplier certification divided by the total suppliers. In the last quarter above the last Quarter 2 of 2018 the total number of suppliers is $65.2 \%$, the results obtained from the number of suppliers in the quarter in Quarter 2 of 2018 found that total suppliers to meet the needs of 46 suppliers with 30 of 46 suppliers already certified and the number of suppliers not certified amounted to 16 .

2. Average Certified Supplier: In this graph explains the average number of certified and non ISO certified suppliers for 16 quarters. In the graph there is a $79.33 \%$ result which is obtained from the average number of certified suppliers from quarter 3 of 2014 to 2nd quarter of 2018 , and $20.77 \%$ obtained from the average number of uncertified suppliers from quarter 3 of 2014 until the second quarter of 2018.

3. History supplier cerified: This graph explains the number of certified and uncertified suppliers in each quarter for 16 quarters.

\section{Conclusion}

Sustainable supply chain management (SSCM) is the implementation of supply chain by integrating cost, environmental, and social aspects. The creation of sustainable supply chain management needs to create a monitoring system that is useful to help companies and stakeholders in assessing and analyzing the achievements of the company in sustainable procurement pengapak. In the monitoring system there is KPI, sustainable procurement KPI obtained with business process mapping on SCOR model. The sustainable KPI obtained amounted to 14 and verified by the company amounted to 8 . The selected KPI was weighted so that the highest final weights result in KPI Source cycle time with final weight is 0.257 and the lowest weight is $\%$ of supplier meeting environmental metric criteria with final weight 0.061456 . From the results of KPI is made into a monitoring system, so that companies can perform monitoring and analyze performance dai on each KPI.

The established monitoring system has 3 layers: the first layer is the hompage that contains information about the total value of each process (source, make, deliver), the value of each attribute in the process, and the value of the whole company. The second layer that contains information about the activities contained in the source engineer to roder. The third layer contains information about the KPI of each process in which there are 3 graphs that describe 16-quarter data history, the graph describes the average of 16 quarters, and the graph describes the current state. With the monitoring system and KPI help companies in implementing sustainable and the company can monitor and analyze the state of the company. The creation of sustainable supply chain management will meet government regulations as well as community demand. 


\section{References}

1. Craig R. Carter, Dale S. Rogers, International Journal of Physical Distribution \& Logistics Management, 38, 5, pp.360-387, https://doi.org/10.1108/09600030810882816. (2008)

2. Ridwan, A.Y. (2015). Proceesing of The 8th International Seminar on Industrial Engineering and Management (ISIEM) (2015)

3. Ariyansyah, M.F.H., Ridwan, A.Y., Andreswari, R. Proceedings of the 11th International Conference of Logistics and Supply Chain Management System (ICLS) (2016)

4. Ridwan, A. Y, Mubassiran, M., \& Syafiq, S."PENGEMBANGAN PROTOTYPE SISTEM MONITORING LOGISTIK BERAS (STUDI KASUS DI BADAN KETAHANAN PANGAN PROVINSI JAWA BARAT)". JRSI (Jurnal Rekayasa Sistem Dan Industri), 2(02), 28-34. (2015)

5. Douglas M. Lambert, Martha C. Cooper, Janus D. Pagh, The International Journal of Logistics Management, 9, 2, pp.1-20, https://doi.org/10.1108/09574099810805807. (1998)

6. Wigaringtyas, L. D., "Pengukuran Kinerja Supply Chain Management dengan Pendekatan Supply Chain Operation Reference (SCOR)”, Jurusan Teknik Industri Universitas Muhammadiyah Surakarta. (2013)

7. Georgise, Fasika B., Thoben Klaus D., Seifert M., WSEAS Transactions on Business and Economics 11, 2014(1):12-31. (2014)

8. Ngatawi, Setyaningsih, I. Universitas Muhammadiyah Surakata 10 No. 1, Juni. (2011)

9. Douglas, M. L., Martha, C. C., \& Janus, D. The International Journal of Logistics Management. MCB UP Ltd. (1998).

10. Supply Chain Council : Supply Chain Operation Reference Model Revision 11.0. (2012)

11. Ita, R. R. Jurnal Gea Vol 7, No 2. Rizki Offset. (2007). 